\title{
PENGARUH PENGGUNAAN METODE INQUIRY DENGAN METODE EKSPOSITORI TERHADAP HASIL BELAJAR MENERAPKAN DASAR-DASAR GAMBAR TEKNIK
}

\author{
Bronson $^{1}$, Asri Lubis ${ }^{2}$ \\ ${ }^{1}$ Alumni Program Studi Pendidikan Teknik Bangunan, Fakultas Teknik UNIMED \\ 2Dosen Pengajar Jurusan Pendidikan Teknik Bangunan, Fakultas Teknik UNIMED \\ (asri2lbs@gmail.com)
}

\begin{abstract}
ABSTRAK
Penelitian ini merupakan Penelitian Eksperimen (Quasi Experiment) yang bertujuan untuk mengetahui pengaruh penggunaan metode yang dapat meningkatkan hasil belajar siswa dalam mata pelajaran Menerapkan dasar-dasar gambar teknik pada kelas X Program Keahlian Teknik Gambar Bangunan di SMK Negeri 1 Lubuk Pakam. Populasi dalam penelitian ini adalah siswa kelas X SMK Negeri 1 Lubuk PakamTahun Ajaran 2014/2015, dengan 2 kelas yang masing-masing kelas jumlah siswanya 32 orang. Pengambilan sample dengan claster sampling, kelas X TGB A dikategorikan sebagai kelas eksperimen dan kelas X TGB B sebagai kelas kontrol. Penelitian ini menggunakan metode inquiry pada kelas eksperimen dan metode Ekspositori pada kelas kontrol. Dalam penelitian ini, ditemukan pada hasil belajar siswa menggunakan metode inquiry dengan nilai rata-rata 84 sedangkan hasil belajar menggunakan metode ekspositori lebih rendah dengan nilai rata-rata 68 . Berdasarkan hasil penelitian dapat disimpulkan, bahwa hasil belajar yang menggunakan metode inquiry lebih tinggi dibandingkan dengan hasil belajar menggunakan metode ekspositori pada mata pelajaran menerapkan Dasar-dasar Gambar Teknik siswa kelas X Program Keahlian Teknik Gambar Bangunan SMK Negeri 1 Lubuk Pakam.
\end{abstract}

Kata Kunci :Metode Inquiry, Metode Ekspositori, dan Hasil Belajar

\begin{abstract}
This study is a research experiment (Quasi Experiment) that aims to determine the effect of the use of methods that can improve student learning outcomes in subjects applying the basics of drawing techniques in class $X$ Architecture Engineering Skills Program at SMK Negeri 1 Lubukpakam. The population in this study were students of class X SMK 1 Lubuk PakamTahun Doctrine of 2014/2015, with 2 classes each class the number of students 32 people. Claster sampling with sampling, class X TGB categorized as an experimental class A and class B TGB X as the control class. This study uses a method of inquiry in the experimental class and the control class Expository method. In this study, it was found in the results of student learning using the method of inquiry with an average value of 84, while learning outcomes using expository method lower with an average value of 68. Based on the results of this study concluded that the results of learning using inquiry method is higher than learning outcomes using expository method on subjects apply Bases Draw Technique class X Architecture Engineering Expertise Program SMK 1Lubuk Pakam.
\end{abstract}

Keywords: Methods of Inquiry, Expository method, and Learning Outcome 


\section{Pendahuluan}

Pendidikan adalah usaha sadar dan terencana untuk mewujudkan suasana belajar dan proses pembelajaran agar siswa secara aktif mengembangkan potensi dirinya untuk memiliki kekuatan spiritual keagamaan, pengendalian diri, kepribadian, kecerdasan, akhlak mulia, serta keterampilan yang diperlukan dirinya masyarakat, bangsa dan juga negara. Pendidikan yang baik merupakan pendidikan yang tidak hanya mempersiapkan siswanya untuk suatu profesi atau jabatan, tetapi untuk menyelesaikan masalah-masalah yang dihadapinya dalam kehidupan seharihari.

Tujuan pendidikan merupakan seperangkat hasil pendidikan yang dicapai oleh siswa setelah diselenggarakan kegiatan pendidikan. Seluruh kegiatan pendidikan, yakni bimbingan pengajaran atau latihan, diarahkan untuk mencapai tujuan pendidikan tersebut. Dalam tujuan pendidikan, harus memiliki tujuan jangka panjang yang artinya, pengetahuan dan keterampilan yang diperoleh siswa berguna sepanjang kehidupan dan tujuan pendidikan bertitik tolak dari tingkah laku yang bersifat operasional. Didalam tujuan pendidikan tersebut juga dilengkapi dengan mutu pendidikan yang menjadi kunci tercapainya tujuan tersebut.

Dalam upaya peningkatan mutu pendidikan banyak hal yang harus diperhatikan, antara lain: hasil belajar, proses belajar mengajar, metode pengajaran yang sesuai dengan materi ajar, fasilitas belajar, dan profesionalisme guru. Proses belajar mengajar merupakan unsur yang paling penting yang harus diperhatikan karena dengan pelaksanaan proses belajar mengajar yang baik tersebut tujuan pendidikan akan tercapai.

Menerapkan Dasar-Dasar Gambar Teknikmerupakan salah satu mata diklat yang dipelajari di kelas X Paket Keahlian Teknik Gambar Bangunan SMK Negeri 1 Lubuk Pakam yang berisikan konsep dasar dalam menggambar bangunan, di mana siswa diharapkan mempunyai pengetahuan, keterampilan dan kemampuan menggambar bangunan yang dapat menjadi bekal bagi siswa nantinya untuk dapat diaplikasikan dan juga dikembangkan dalam dunia kerja.

Pada mata pelajaranMenerapkan DasarDasar Gambar Tekniksiswa harus dapat mengetahui jenis-jenis peralatan yang dipakai untuk menggambar dan cara-cara dasar dalam menggambar. Dasar menggambar sangat penting dipelajari karena sebagai titik awal dalam menggambar agar mendapatkan hasil belajar yang baik. Untuk dapat mempelajari mata diklat yang lainnya pengetahuan dasar menggambar teknik bangunan sangat perlu karena mata pelajaran Menerapkan DasarDasar Gambar Teknik erat hubungannya dengan mata pelajaran lainnya seperti Memahami Ilmu Bangunan Gedung. Dengan menguasai mata pelajaran menerapkan dasardasar gambar teknik maka siswa mampu menggunakan alat-alat gambar dan membuat gambar benda tiga dimensi, menggambar proyeksi benda, menggambar proyeksi bangunan. Mata pelajaran ini diajarkan dengan harapan dapat memberikan keterampilan dan pengetahuan kepada siswa sebagai modal nantinya untuk bekerja pada perusahaan konsultan bangunan.

Namun kenyataannya, kemampuan dan keterampilan mata diklat Menerapkan DasarDasar Gambar Teknik dari siswa kelas X Program Keahlian Teknik Gambar Bangunan SMK Negeri 1 Lubuk Pakam sekarang ini masih jauh dari yang diharapkan. Hal ini dapat dilihat dari hasil observasi di SMK Negeri 1 Lubuk Pakam melalui Daftar Kumpulan Nilai (DKN), peneliti menemukan bahwa hasil belajar siswa kelas X Program Keahlian Teknik Gambar Bangunan SMK Negeri 1 Lubuk Pakam Tahun Ajaran 2013/2014 pada semester genap bahwa dari 30siswa, yang memperoleh nilai $<70$ sebanyak 10 siswa, memperoleh nilai 70 - 79 sebanyak 15 siswa, memperoleh nilai 80 - 89 sebanyak 5siswa dan memperoleh nilai 90 - 100tidak ada, dengan Kriteria Ketuntasan Minimum (KKM) yang berlaku di sekolah SMK Negeri 1 Lubuk Pakam tersebut sebesar 70.

Dengan demikian dapat diketahui penurunan hasil belajar siswa kelas X SMK Negeri 1 Lubuk Pakam dalam mempelajari menerapkan dasar-dasar gambar teknik. Hal ini disebabkan oleh beberapa kendala dari siswa, seperti; 1) Siswa SMK lebih dominan untuk lebih banyak praktek langsung sedangkan pendalaman materi sangatlah dibutuhkan agar dapat melakukan prakteknya dengan maksimal. 2) Siswa kurang memahami cara penyampaian materi karena penyampaian materi oleh guru yang cenderung menerangkan 
materinya dengan ceramah, 3) Siswa kurang memahami pelajaran menerapkan dasar-dasar gambar teknik karena tidak memiliki semangat, motivasi, dan keterampilan. 4) Guru kurang aktif dalam mengarahkan murid agar termotivasi, ingin tahu, dan lebih aktif dalam memahami dan mengetahui materi pelajaran. Sebagai tenaga pendidik, guru harus mampu memperhatikan, memahami dan meningkatkan perkembangan keterampilan siswa, pengetahuan siswa serta pemahaman siswa terhadap materi pelajaran. Penurunan hasil belajar siswa ini disebabkan oleh pembelajaran yang didominasi dengan metode penyampaian materi secara verbal dari seorang guru kepada kelompok siswa yang disebut dengan metode ekspositori.

Metode ekspositori lebih banyak diberikan melalui ceramah, maka akan sulit mengembangkan kemampuan siswa dalam hal kemampuan keterampilan, sosialisasi, hubungan interpersonal, serta kemampuan dalam berpikir kritis. Akibatnya siswatidak memiliki banyak pengetahuan, materi yang diajarkan terlintas begitu saja tanpa pemahaman dan pendalaman khusus dari guru, dan juga siswatidak dilatih untuk menemukan pengetahuan dan konsep menerapkan dasar-dasar gambar teknik, sehingga siswa cenderung lebih cepat bosan dalam mengikuti pelajaran, siswa tidak paham pada materi yang diajarkan, bakat dan keterampilan siswa dalam menggambar teknik tidak mengalami perubahan yang baik dan akibatnya berdampak pada rendahnya hasil belajar siswa pada mata pelajaran menerapkan dasar-dasar gambar teknik.

Untuk meningkatkan hasil belajar yang diperoleh siswayaitu melalui kegiatan belajar mengajar yang baik, membangkitkan rasa ingin tahu siswa terhadap pelajaran yang dipelajari, menumbuhkan semangat untuk mencari lebih dari yang disampaikan oleh guru dan tidak lepas dari pengaruh salah satu aspek yang turut menentukan keberhasilan pembelajaran yaitu metode pembelajaran. Metode pembelajaran harus dikuasai oleh guru agar dalam proses pembelajaran guru dapat menyampaikan materi pelajaran dengan baik. Apabila guru tidak menguasai metode pembelajaran yang cocok untuk pembelajaran tersebut maka pelajaran tersebut tidak akan tersampaikan dengan baik. Oleh karena itu diperlukan kemampuan dan pengetahuan dalam menggunakan metode yang cocok agar hasil belajar dapat tercapai dansiswa pun memiliki pengetahuan, pemahaman, dan keterampilan yang baik. Sebagai salah satu pemecahan dalam masalah ini dipilih pendekatan pembelajaran yang lebih sesuai yaitu; dengan metode inquiry.

Berdasarkan latar belakang diatas maka peneliti tertarik untuk melakukan penelitian untuk mengetahui apakah Penggunaan Metode Inquiry Dengan Metode Ekspositori Berpengaruh Terhadap Hasil Belajar Menerapkan Dasar-Dasar Gambar Teknik Pada Siswa Kelas X Program Studi Keahlian Teknik Gambar Bangunan SMK Negeri 1 Lubuk

\section{Kajian Pustaka}

\subsection{Hakikat Hasil Belajar Dasar-Dasar} Gambar Teknik

Belajar adalah tahapan perubahan seluruh tingkah laku individu yang relatif menetap sebagai hasil pengalaman dan interaksi dengan lingkungan yang melibatkan proses kognitif. Menurut Sagala (2009 : 13) menyatakan belajar merupakan proses terbentuknya tingkah laku baru yang disebabkan individu merespon lingkungannya, melalui pengalaman pribadi yang tidak termasuk kematangan dan pertumbuhan.

Hasil belajar merupakan kemampuan yang diperoleh anak setelah melalui kegiatan belajar. Sudjana (2005:3) "Hasil belajar adalah perubahan tingkah laku yang mencakup bidang kognitif, afektif dan psikomotor yang dimiliki siswa setelah menerima pengalaman belajarnya."Dalam kegiatan belajar yang telah diprogram, tujuan belajar telah ditetapkan lebih dahulu oleh guru. Anak yang berhasil dalam belajar adalah anak yang berhasil mencapai tujuan pembelajaran atau tujuan intruksional.

Hasil belajar biasanya dinyatakan dalam bentuk skor yang diperoleh siswa setelah mengikuti suatu tes hasil belajar yang dilakukan setelah selesai program pengajarandengan mengacu pada indikator dan keterampilan berpikir tertentu. Hal ini sejalan dengan yang diungkapkan oleh Sudjana (2005 : 22) bahwa prestasi belajar adalah penilaian dari usaha kegiatan yang dinyatakan dalam bentuk angka, huruf yang dapat mencerminkan hasil yang oleh seseorang dalam jangka waktu tertentu.

Hasil belajar yang dimaksud dalam penelitian ini adalah hasil belajar menerapkan dasar-dasar gambar teknik yaitu pencapaian peningkatan proses belajar mengajar terhadap 


\section{Bronson - Asri Lubis}

mata pelajaranmenerapkan dasar-dasar gambar teknik. Menerapkan Dasar-Dasar Gambar Teknik merupakan mata pelajaran yang diajarkan di SMK program studi keahlian Teknik Gambar Bangunan. Mata pelajaran ini termasuk salah satu mata pelajaran kejuruan yang bertujuan pada penguasaan bagaimana menggambar suatu konstruksi dengan manual sebagai dasar pengetahuan menggambar.

\subsubsection{Hasil Belajar menurut Taksonomi Bloom}

Para ahli mencoba membuat kategori jenis-jenis belajar yang dikenal dengan taksonomi belajar salah satu yang terkenal adalah taksonomi yang disusun oleh Benyamin S. Bloompada tahun 1956 dalam buku Arikunto Suharsimi (2005). Tujuan pendidikan dapar dirumuskan pada tiga tingkatan, pertama, tujuan umum pendidikan yang menentukan perlu tidaknya suatu program diadakan. Kedua, tujuan yang didasarkan atas tingkah laku, yang dimaksud berhasilnya pendidikan dalam bentuk tingkah laku yang dimaksud dengan taksonomi. Ketiga, tujuan yang lebih jelas yang dirumuskan secara operasional. Kaum behavioris berpendapat bahwa taksonomi yang dikemukakan oleh Bloom dan kawan-kawan adalah bersifat mental. Taksonomi ini merupakan kriteria yang dapat digunakan oleh guru untuk mengevaluasikan mutu tujuannya. Salah satu manfaat taksonomi adalah bahwa guru didorong untuk bertanya adakah ia menekankan segi tertentu atau tidak.

Taksonomi Bloom terdiri dari tiga kategori yaitu yang dikenal sebagai domain atau ranah kognitif, ranah afektif dan ranah psikomotorik. Yang dimaksud dengan ranah-ranah ini oleh Bloom adalah perilakuperilaku yang memang diniatkan untuk ditunjukan oleh siswa atau pelajar dalam cara-cara tertentu, misalnya bagaimana mereka berpikir (kognitif), bagaimana mereka bersikap dn mereka merasakan sesuatu (afektif), dan bagaimana mereka berbuat (psikomotorik). Dalam mengukur kemampuan sesorang siswa maka para guru harus memperhatikan ketiga ranah tersebut.

\subsubsection{Kemampuan Kognitif}

Kemampuan kognitif adalah kawasan yang berkaitan dengan aspek-aspek intelektual atau secara logis yang biasa diukur dengan pikiran atau nalar. Kawasan ini terdiri dari:

a. Pengetahuan, mencakup ingatan akan hal-hal yang pernah dipelajari dan disimpan dalam ingatan.

b. Pemahaman, mengacu pada kemampuan memahami makna materi.

c. Penerapan, mengacu pada kemampuan menggunakan atau menerapkan materi yang sudah dipelajari pada situasi yang baru dan menyangkut penggunaan aturan atau prinsip.

d. Analisis, mengacu pada kemampuan menguraikan materi kedalam komponen-komponen atau faktor penyebabnya, dan mampu memahami hubungan diantara bagian yang satu dengan yang lainnya sehingga struktur dan aturannya dapat lebih dimengerti.

e. Evaluasi, mengacu pada kemampuan memberikan pertimbangan terhadap nilai-nilai materi untuk tujuan tertentu.

\subsection{Hakikat Metode Pembelajaran Inquiry}

Metode mengajar yang diterapkan dalam suatu pengajaran dikatakan efektif jika menghasilkan sesuatu sesuai dengan yang diharapkan atau dengan kata lain tujuan tercapai. Metode mengajar dikatakan efisien jika penerapannya dalam menghasilkan sesuatu yang diharapkan itu relatif menggunakan tenaga, usaha, pengeluaran biaya, dan waktu minimum atau semakin kecil tenaga, usaha, biaya dan waktu yang dikeluarkan maka dapat dikatakan semakin efisien.

Menurut Sanjaya (2006: 196) metode inquiry merupakan kegiatan pembelajaran yang menekankan pada proses berpikir secara kritis dan analistis untuk mencari dan menemukan sendiri jawaban dari suatu masalah yang dipertanyakan. Proses bepikir itu sendiri biasanya dilakukan melalui tanya jawab antara guru dan siswa. Metode pembelajaran ini sering juga disebut dengan metode heuristic, yang berasal dari bahasa Yunani, yaitu heuriskein yang berarti saya menemukan. Menurut Uzer Usman (1993:124) metode inquiry adalah "suatu cara menyampaikan pelajaran dengan penelaahan sesuatu yang bersifat mencari secara kritis, analisis, dan ilmiah dengan menggunakan langkah-langkah tertentu menuju kesimpulan.

Upaya mengembangkan disiplin intelektual dan keterampilan yang dibutuhkan 
siswa untuk membantu memecahkan masalah dengan memberikan pertanyaan-pertanyaan yang memperoleh jawaban atas dasar rasa ingin tahu merupakan bagian proses metodeinquiry. Keterlibatan aktif secara mental dalam kegiatan belajar yang sebenarnya. Metode ini secara koperatif memperkaya cara berpikir siswa dan mendorong mereka hakekat timbulnya pengetahuan tentative dan berusaha menghargai penjelasan.

Dalam Abdullah Ridwan (2013 : 117 ) prinsip metodeinquiry merupakan upaya dalam mengajar yang berusaha meletakkan dasar dan mengembangkan cara berpikir ilmiah, pendekatan ini menempatkan lebih banyak belajar sendiri, mengembangkan kekreatifan dalam menyelesaikan masalah. Siswa betulbetul ditempatkan sebagai subjek yang belajar sedangkan peranan guru dalam metodeinquiry adalah pembimbing belajar dan fasilitator belajar. Tugas utama guru adalah memilih masalah yang perlu dilontarkan kepada kelas untuk dipecahkan oleh siswa sendiri.

Metode Inquiry dalam mengajar termasuk pendekatan modern, yang sangat didambakan untuk dilaksanakan disetiap sekolah. Kegiatan ini dilakukan saat tatap muka atau saat kegiatan bukan komunikasi satu arah atau komunikasi sebagai peran aksi. Inquiry dalam pembelajaran dapat lebih membiasakan kepada siswa untuk membuktikan sesuatu mengenai materi pelajaran yang sudah dipelajari. Dengan menggunakan metodeinquiry ini perkembangan kognitif siswa lebih terarah dan dalam kehidupan sehari-hari dapat diaplikasikan secara motorik.

Menurut Sanjaya (2006: 202) Secara umum dalam proses pembelajaran dengan menggunakan metode inquiry dapat mengikuti langkah-langkah sebagai berikut:

a. Guru menjelaskan topik, tujuan, dan hasil belajar yang diharapkan dapat dicapai oleh siswa.

b. Guru menjelaskan pokok-pokok kegiatan yang harus dilakukan oleh siswa untuk mencapai tujuan dan menjelaskan pentingnya kegiatan belajar untuk membangkitkan motivasi belajar siswa.

c. Guru memberikan tugas kepada siswa untuk mencari dan mendapatkan jawaban secara pasti.

d. Guru memberikan penjelasan terhadap persoalan yang mungkin membingungkan siswa. e. Guru mengajukan pertanyaan yang dapat mendorong siswa untuk berpikir mencari informasi atau mengumpulkan data yang dibutuhkan.

f. Guru menentukan jawaban yang dianggap diterima sesuai dengan data atau informasi yang diperoleh berdasarkan pengumpulan data.

g. Merangkum dalam bentuk rumusan sebagai kesimpulan yang akurat dan mampu menunjukkan kepada siswa data mana yang relevan.

\subsection{Hakikat Metode Pembelajaran Ekspositori}

Metode pembelajaran ekspositori metupakan metode pembelajaran yang digunakan dengan memberikan keterangan terlebih dahulu, defenisi, prinsip dan konsep materi pembelajaran serta memberikan contohcontoh latihan masalah dalam bentuk ceramah, demonstrasi, penugasan dan tanya jawab, sedangkan siswa mengikuti pola yang ditetapkan oleh guru secara cermat. Metode ekspositori merupakan metode pembelajaran yang mengarah kepada tersampaikannya isi pelajaran kepada siswa secara langsung. Metode ekspsitori sering disamakan dengan metode ceramah, karena sama-sama memberikan informasi.Soemantri (2001:45) membedakan metode ekspositori dan metode ceramah, mengingat dominasi guru dalam metode ekpositori banyak dikurangi. Guru tidak terus bicara, informasi informasi diberikan pada saat atau bagian-bagian yang diperlukan, seperti awal pelajaran.

Ekspositori adalah suatu cara untuk menyampaikan gagasan atau ide dalam memberikan info dengan lisan atau tulisan". Selanjutnya Mujiono dan Dimyati (1994 : 172) menyatakan bahwa metode ekspositori adalah memindahkan pengetahuan, keterangan dan nilai kepada siswa".

Didalam sebuah pelaksanaan pembelajaran yang menggunakanmetode ekspositori, guru cenderung mengontrol proses pembelajaran dengan aktif, sementara siswa relatif pasif menerima dan mengikuti apa yang disajikan oleh guru. Pembelajaran ekspositori ini merupakan proses pembelajaran yang lebih berpusat pada guru (teacher center), guru menjadi sumber pemberi informasi utama meskipun dalam strategi pembelajarannya digunakan metode selain ceramah dan dilengkapi atau didukung dengan penggunaan media, penekanannya pada proses penerimaan 
pengetahuan (materi pelajaran) bukan pada proses pencarian konstruksi pengetahuan.

Peranan guru dalam metode ekspositori merupakan pembimbing program pelajaran karena merupakan programer. Guru harus melihat program pelajaran yang telah ditetapkan untuk dijelaskan dan siswa harus dapat menguasainya. Guru merupakan sumber data yang penting dan merupakan komponen pemindah antara sumber pengajaran dengan siswa. Peranan guru ialah membimbing siswa untuk mendapatkan informasi yang benar, yang merupakan bagian dari kurikulum yang dipersyaratkan.

\subsection{Menguji Keunggulan Metode Pembelajaran Inquiry dengan Metode Pembelajaran Ekspositori yang Memberikan Pengaruh lebih baik Dalam Meningkatkan Hasil Belajar Dasar-Dasar Gambar Teknik}

Dalam proses pembelajaran menggunakan metode inquiry, guru menjelaskan materi dan memberikan pengetahuan yang berhubungan dengan tujuan pembelajaran. Diharapkan siswa lebih berpikir kreatif dan aktif dalam mengaplikasikan pengetahuannya. Konsepkonsep dalam masalah atau tugas yang diberikan oleh guru adalah konsep-konsep yang sudah diketahui oleh siswa yang sebelumnya sudah diberikan pemahaman oleh guru. Dalam pelaksanaannya metode inquiry siswa lebih berperan aktif dalam menemukan sendiri jawabannya dan guru sebagai instruktur mengarahkan siswa untuk menemukan jawabannya agar tidak salah persepsinya.

Dalam pembelajaran menggunakan metode ekspositori pada kenyataannya kegiatan pembelajaran banyak didominasi oleh guru, siswa kurang aktif dalam pencarian konsep, prinsip atau pengertian materi yang dipelajari. Dalam proses pembelajaran siswa menerima bahan pembelajaran yang telah disusun oleh guru, media, dan sumber belajar yang telah ditentukan oleh guru.

Dengan demikian maka penggunaan metode Inquirydapat memberikan pengaruh lebih baik dari pada metode ekspositori, karena dalam metode inquirysiswa dirangsang untuk berpikir lebih aktifuntuk menemukan sendiri jawaban dari pertanyaan atau tugas yang diberikan sesuai dengan tujuan pembelajaran dan arahan dari guru. siswa lebih kreatif dalam menggunakan pola pikirnya untuk memahami materi dan mampu mengaplikasikan pengetahuannya sesuai dengan konsep-konsep yang diberikan oleh guru.

\subsection{Hipotesis Penelitian}

Metode mengajar pada dasarnya adalah tindakan nyata dari guru atau merupakan praktek guru melaksanakan pengajaran melalui cara tertentu yang dinilai lebih efektif dan efisien. Dengan kata lain metode mengajar adalah politik taktik yang digunakan guru dalam proses pembelajaran di kelas. Politik atau taktik tersebut, harus mencerminkan langkah-langkah yang sistematik. Karena itu pendidik dituntut untuk memiliki kemampuan mengatur secara umum komponen-komponen pembelajaran, sehinggga terjalin keterkaitan fungsi antar komponen pembelajaran dimaksud.

Berdasarkan dekripsi diatas, maka hipotesis penelitian ini adalah penggunaan metode inquiry dapat memberikan pengaruh hasil belajar yang lebih tinggi dari pada metode ekspositori dalam meningkatkan hasil belajar menerapkan dasar-dasar gambar teknik.

\section{Metodologi Penelitian}

Penelitian ini dilaksanakan di SMK Negeri 1 Lubuk Pakam Program Studi Keahlian Teknik Gambar Bangunan pada Mata Pelajaran MenerapkanDasar-Dasar Gambar Teknik. Penelitian ini dilaksanakan pada bulan Februari Tahun Ajaran 2014/2015.

Populasi penelitian ini adalah seluruh siswa kelas X Program Studi Keahlian Teknik Gambar Bangunan, Tahun Ajaran 2014/2015, yaitu terdiri dari dua kelas masing-masing 32 orang. Pengambilan sampel dilakukan dengan Claster Sampling yaitu: kelas $X$ TGBA dikategorikan sebagai kelas eksperimen dan kelas X TGBB sebagai kelas control.

Penelitian ini termasuk penelitian quasiexperiment/eksperimen semu. Dalam penelitian eksperimen semu, pretes-postes group control tidak secara random. Pada pelaksanaan penelitian ini dilibatkan dua perlakuan yang berbeda antara kelas eksperimen dan kelas kontrol.

\subsection{TeknikPengumpulan Data}

Tes kognitif hasil belajar siswa adalah seperangkat tes kognitif dalam bentuk objektif tes dengan pilihan berganda sebanyak 23 soal dengan 4 pilihan jawaban. dimana 12 soal 
untuk siklus pertama (I) dan 11 soal untuk siklus kedua (II).

\subsection{Hasil uji coba instrumen}

Dari hasil uji coba instrumen yang dilakukan di kelas XII pada mata pelajaran MenerapkanDasar-Dasar Gambar TeknikTahun Ajaran 2014/2015. Pada uji instrument diperoleh soal yang valid sebanyak 25 butir soal dan soal yang tidak valid sebanyak 5 butir soal yaitu no 5, 11, 24, 29, 30 .

\subsection{Teknik Analisis Data}

Teknik analisis data dilakukan dengancara melakukan; Uji Normalitas, Uji Homogenitas, Uji Hipotesis. Pada Tahapan Uji Normalitasdata dilakukan untuk mengetahui normal tidaknya data peneliti dari tiap variabel penelitian. Uji normalitas yang digunakan dalam penelitian ini adalah uji liliefors, Tahapan Uji Homogenitas yang digunakan adalah cara varians terbesar dibandingkan dengan varians terkecil, dengan menggunakan uji $\mathrm{f}$ dan Uji Hipotesis Uji hipotesis yang digunakan dalam penelitian ini adalah uji beda dengan uji satu pihak, yaitu uji pihak kanan dengan $\alpha=0,05$, jika $t$ hitung $>\mathrm{t}$ tabel, maka Ha diterima dan Ho ditolak.

\section{Hasil Penelitian Dan Pembahasan}

Dalam penelitian ini terdapat jumlah siswa 64 orang yang masing-masing pada kelas eksperimen adalah 32 siswa dan pada kelas kontrol terdapat 32 siswa. Setiap kelas perlakuan dilakukan dengan memberikan pre tes dan kemudian pada akhir perlakuan dilakukan post tes

\subsection{DataTes Hasil Belajar Siswa Kelas Eksperimen Dengan Metode Inquiry}

\subsubsection{Pre Tes}

Pada kelas kelas eksperimen sebelum diberikan perlakuan dengan metode inquiry, diperoleh skor tertinggi sebesar 22 , skor terendah 13 , nilai rata-rata 69, standar deviasi 2,282, dan varians 5,208 .

Tabel 1. Hasil Pre Tes Metode Inquiry

\begin{tabular}{cccc}
\hline Kelas & $\begin{array}{c}\text { Interval } \\
\text { Kelas }\end{array}$ & $\begin{array}{c}\text { F. } \\
\text { Absolut }\end{array}$ & Fr (\%) \\
\hline 1 & $13-14$ & 5 & 15.6250 \\
2 & $15-16$ & 6 & 18.750
\end{tabular}

\begin{tabular}{cccc}
3 & $17-18$ & 10 & 31.250 \\
4 & $19-20$ & 8 & 25 \\
5 & $21-22$ & 3 & 9.375 \\
6 & $23-24$ & 0 & 0 \\
\hline & Jumlah & 32 & 100 \\
\hline
\end{tabular}

\subsubsection{Post Test}

Pada kelas kelas eksperimen setelah diberikan perlakuan dengan metode inquiry, diperoleh skor tertinggi sebesar 25, skor terendah 14 , nilai rata-rata 84 , standar deviasi 2,967, dan nilai varians 8,805 .

Tabel 2. Hasil Post Tes Metode Inquiry

\begin{tabular}{|c|c|c|c|}
\hline Kelas & $\begin{array}{c}\text { Interval } \\
\text { Kelas }\end{array}$ & $\begin{array}{c}\text { F. } \\
\text { Absolut }\end{array}$ & $\operatorname{Fr}(\%)$ \\
\hline 1 & $14-15$ & 2 & 6.2500 \\
\hline 2 & $16-17$ & 2 & 6.250 \\
\hline 3 & $18-19$ & 4 & 12.500 \\
\hline 4 & $20-21$ & 9 & 28.125 \\
\hline 5 & $22-23$ & 7 & 21.875 \\
\hline 6 & $24-25$ & 8 & 25 \\
\hline & 32 & 100 \\
\hline
\end{tabular}

4.2 Data Hasil Belajar Siswa pada Kelas Kontrol dengan Metode Ekspositori

\subsubsection{Pre Tes}

Berdasarkan data yang diperoleh

Tabel 3. Data Pre Tes Metode Ekspositori

\begin{tabular}{cccc}
\hline Kelas & $\begin{array}{c}\text { Interval } \\
\text { Kelas }\end{array}$ & $\begin{array}{c}\text { F. } \\
\text { Absolut }\end{array}$ & Fr (\%) \\
\hline 1 & $10-11$ & 3 & 9.3750 \\
2 & $12-13$ & 9 & 28.125 \\
3 & $14-15$ & 8 & 25.000 \\
4 & $16-17$ & 2 & 6.25 \\
5 & $18-19$ & 5 & 15.625 \\
6 & $20-21$ & 5 & 15.625 \\
\hline \multicolumn{2}{c}{ Jumlah } & 32 & 100 \\
\hline
\end{tabular}

sebelum diberikan perlakuan dapat diketahui bahwa skor pre-tes pada kelas kontrol diperoleh skor tertinggi $=21$ dan skor terendah $=10$, dengan rata-rata $=47$, standart deviasi $(\mathrm{SD})=3,276$ dan varians $=$ 10,738 


\section{Bronson - Asri Lubis}

Tabel 4. Hasil Pre Tes Metode Ekspositori

\begin{tabular}{cccc}
\hline Kelas & $\begin{array}{c}\text { Interval } \\
\text { Kelas }\end{array}$ & $\begin{array}{c}\text { F. } \\
\text { Absolut }\end{array}$ & Fr (\%) \\
\hline 1 & $13-14$ & 7 & 21.8750 \\
2 & $15-16$ & 8 & 25.000 \\
3 & $17-18$ & 3 & 9.375 \\
4 & $19-20$ & 12 & 37.5 \\
5 & $21-22$ & 2 & 6.250 \\
6 & $23-24$ & 0 & 0.000 \\
\hline \multicolumn{2}{c}{ Jumlah } & 32 & 100 \\
\hline
\end{tabular}

\subsubsection{Post Tes}

Berdasarkan data yang diperoleh setelah diberikan perlakuan dapat diketahui bahwa skor post-tes pada kelas kontrol diperoleh skor tertinggi $=21$ dan skor terendah $=13$, dengan rata-rata $=68$, standart deviasi $(\mathrm{SD})=2,495$, dan varians $=6,224$.

\subsection{Pembahasan Penelitian}

Penelitian yang dilakukan di SMK Negeri 1 Lubuk Pakam bertujuan untuk mengetahui pengaruh metode inquiry terhadap hasil belajar siswa pada materi menggambar proyeksi benda berdasarkan ilmu konstruksi bangunan. Penelitian ini tergolong dalam penelitian quasi eksperimen yang melibatkan dua kelas yaitu kelas X TGB-A dan kelas X TGB-B yang diberi pelakuan yang berbeda, yaitu kelas eksperimen dengan metode inquiry dan kelas kontrol dengan metode ekspositori.

Dalam penelitian ini hipotesis bahwa hasil belajar yang diajarkan dengan metode Inquiry lebih tinggi dari pada hasil belajar yang diajarkan dengan metode ekspositori adalah terbukti. Hal tersebut ditunjukkan oleh nilai $\mathrm{t}$ hitungsebesar 5,8365, dikonsultasikan dengan $t_{\text {tabel }}$ pada taraf signifikan sebesar 0,05 untuk $\mathrm{n}$ 32 sebesar 2,030 atau 5,8365 > 2,030 menunjukkan bahwa hipotesis diterima.

\section{Kesimpulan dan saran}

\subsection{Kesimpulan}

Dari hasil analisis data dan pembahasan Penggunaan Metode Ekspositori yang didukung dan difasilitasi oleh guru membuat siswa berfokus pada pengetahuan yang disampaikan guru dan tidak ada penggalian pemahaman yang khusus pada materi yang dipelajari sedangkan pada penggunaan metode Inquiry, siswa diajak untuk mencari tahu inti dari permasalahan-permasalahan yang diberikan oleh guru berdasarkan materi yang secara singkat dipaparkan sesuai dengan hasil yang diharapkan. Sehingga siswa yang diajarkan dengan menggunakan metode Inquiry lebih memahami dan dapat mengingat dalam jangka yang panjang sedangkan siswa yang diajarkan dengan ekspositori cenderung kurang mendalami materi yang dipelajari.

Hasil belajar pada materi pelajaran Menerapkan dasar-dasar gambar teknik kelas eksperimen yang diajarkan dengan metode inquiry lebih tinggi daripada kelas yang diajarkan dengan metode ekspositori. Hal ini dapat dilihat dari rata-rata hasil belajar dari masing-masing kedua kelas, dimana rata-rata hasil belajar pada kelas eksperimen sebesar 84, sedangkan rata-rata hasil belajar pada kelas kontrol sebesar 68 .

Berdasarkan uji $t$, hipotesis diterima yaitu Hasil belajar siswa yang diajarkan dengan menggunakan metode inquiry lebih tinggi daripada hasil belajar siswa yang diajarkan dengan menggunakan metode ekspositori.

\subsection{Saran}

Berdasarkan hasil penelitian, kesimpulan maka perlu disarankan beberapa hal sebagai berikut:

a. Hendaknya metode inquiryditerapkan dalam proses pembelajaran agar diperoleh peningkatan hasil belajar yang lebih maksimal.

b. Bagi peneliti yang lain yang ingin mengembangkan penelitian ini lebih lanjut agar kiranya melakukan dengan masalah yang lain.

c. Hendaknya guru dapat mengetahui metodemetode yang baik digunakan dalam tiap mata pelajaran yang diajarkan terutama pada metode Inquiry.

\section{Daftar Pustaka}

Abdullah Ridwan Sani.(2013). Inovasi Pembelajaran. Jakarta: Bumi Aksara.

Andi W Gunawan, (2012). Tuntaskan Pembelajaran Efektif Dengan Metode Pengajaran Efektif. Jakarta: Bumi Aksara.

Anita L. Archer \& Charles A. Hughes. (2011). Explicit Instruction Effective and Efficient Teaching. New York: The Guilford Press. Diaksespada 16 April 
2014

darihttp:/ / explicitinstruction.org/

Arikunto Suharsimi. (2005). Dasar-dasar Evaluasi Pendidikan (Edisi Revisi). Jakarta : Bumi Aksara.

Hamid Darmadi, M.Pd. (2013). Metode Penelitian Pendidikan Dan Sosial. Bandung: Alfabeta.

Mudjiono dan Dimyati, (1994). Belajar dan Pembelajaran. Jakarta: Rineka Cipta.

Nawawi, H. (2009). Strategi Belajar-Mengajar. Jakarta: UI Press.

Purwanto, Gadung dan Raharjo Tentrem. (2002). Menggambar Teknik Dasar. Yogyakarta : Kanisius.

Ro'iyatunisa. A (2013) Peran Guru Pada Implementasi Kurikulum 2013. Diakses pada 5 juni 2014 dari http://anisroiyatunisa-blogspot. com/2013/04/peranan-guru-dalamimplementasi.html.

Sagala, Syaiful. (2003). Konsep dan Makna Pembelajaran. Bandung: Alfabeta.

Sudjana, N. (2003) Teknik Analisis Regresi Dan Korelasi bagi Para Peneliti. Bandung: Tarsito.

Sudjana, N. (2005) Penilaian Hasil Proses Belajar Mengajar. Bandung: PT. Remaja Rosdakarya.

Sugiyono. (2003) Statistika Untuk Penelitian.Bandung: Alfabeta.

Suparno. (2008), "Teknik Gambar Bangunan unntuk SMK Jilid I". Direktorat PSMK

Usman, M.Uzer dan Setiawati, Lilis. (1993).Upaya Optimalisasi Kegiatan Belajar Mengajar, Bandung:PT.Remaja Rosdakarya.

Wina Sanjaya, M.Pd, (2006). Strategi Pembelajaran Berorientasi Standar Proses Pendidikan. Jakarta: Kencana 